\title{
Enhancement of hatching and trophoblastic outgrowth by mouse embryos cultured in Whitten's medium containing plasmin and plasminogen*
}

\author{
A. R. Menino, Jr and J. L. O'Claray \\ College of Agriculture, University of Hawaii, Hilo, Hawaii 96720, U.S.A.
}

\begin{abstract}
Summary. Mice were induced to superovulate and 2-cell embryos were cultured in Whitten's medium with $10 \mathrm{mg}$ bovine serum albumin/ml (WM) as control, Medium WM with $2 \cdot 3,4 \cdot 6,23 \cdot 1$ or $46 \cdot 2 \mu \mathrm{g}$ plasmin $/ \mathrm{ml}$, Medium WM with $14 \cdot 6,29 \cdot 1$ or $145 \cdot 7 \mu \mathrm{g}$ plasminogen $/ \mathrm{ml}$, Medium WM with $0 \cdot 1,0 \cdot 2,1 \cdot 1$ or $2 \cdot 2 \mu \mathrm{g}$ trypsin $/ \mathrm{ml}$, Medium WM with $0.2,0.3,1.6$ or $3.3 \mu \mathrm{g}$ pronase $/ \mathrm{ml}$ and Medium WM with $10 \%$ heat-treated bovine serum (HTBS). Proteolytic activities in the culture media were evaluated at the start of the culture period and 10 days later. Blastocyst formation was significantly reduced in cultures supplemented with pronase and in the two higher levels of trypsin when compared to that in Medium WM. More embryos developed to the blastocyst stage in Medium WM +2.3 or $23.1 \mu \mathrm{g}$ plasmin $/ \mathrm{ml}$ and Medium WM $+14.6 \mu \mathrm{g}$ plasminogen/ $\mathrm{ml}$ than in Medium WM $(P<0.05)$. The incidence of hatching was significantly greater in Medium WM than in all plasminogen- and plasmin-supplemented media except for Medium WM $+29 \cdot 1 \mu \mathrm{g}$ plasminogen $/ \mathrm{ml}$. Although not significantly different, hatching was lower in Medium WM and Medium WM $+0 \cdot 1 \mu \mathrm{g}$ trypsin $/ \mathrm{ml}$ when compared to Medium WM + HTBS. Similar numbers of embryos completed the hatching process in Media WM, WM +0.1 or $0.2 \mu \mathrm{g}$ trypsin $/ \mathrm{ml}$ and $\mathrm{WM}+0.3 \mu \mathrm{g}$ pronase $/ \mathrm{ml}$. Since dissolution of the zona pellucida occurred within $96 \mathrm{~h}$ for embryos cultured in Media WM +1.6 or $3.3 \mu \mathrm{g}$ pronase/ml and $\mathrm{WM}+1.1$ or $2.2 \mu \mathrm{g}$ trypsin/ $\mathrm{ml}$, hatching could not be evaluated. The incidence of attachment and subsequent trophoblastic outgrowth was significantly greater in media with plasmin, plasminogen and HTBS than in pronase- and trypsin-supplemented media or in Medium WM alone. The results suggest that the enhancement in embryo development observed in plasminand plasminogen-supplemented media is due not only to the provision of protease but to an additional trophic effect as well. Simple medium supplemented with plasmin or plasminogen is as able to support in-vitro development as is medium supplemented with serum.
\end{abstract}

\section{Introduction}

The process of blastocyst escape from the zona pellucida appears to be dependent upon two processes: expansion of the blastocoele and structural weakening of the zona pellucida. Blastocoelic expansion has been reported as prostaglandin-dependent since several nonsteroidal anti-inflammatory drugs, including indomethacin and meclofenamic acid, and inhibitory analogues of prostaglandins $\mathrm{E}$ and F- $2 \alpha$ limit expansion and reduce hatching (Biggers, Leonov, Baskar \& Fried, 1978; Baskar et al., 1981; Hurst \& MacFarlane, 1981). Weakening or lysis of the zona pellucida is believed to be due to a zona lysin of uterine origin which may also have a role in

* Reprint requests to Dr A. R. Menino, Jr, Department of Animal Science, Oregon State University, Corvallis, OR 97331-6702, U.S.A. 
initiating implantation (McLaren, 1970; Mintz, 1972; Hoversland \& Weitlauf, 1981, 1982). The identity of the zona lysin remains an enigma; it may be secreted in active form or as a proenzyme to be activated by embryonic enzymes as proposed by Denker \& Hafez (1975). Joshi \& Murray (1974) and Rosenfeld \& Joshi $(1977,1981)$ have implicated an oestrogen-dependent rat uterine-specific endopeptidase in zona lysis. Hoversland \& Weitlauf $(1981,1982)$ have observed that the incidence of zona lysis in ovariectomized mice treated with oestradiol and progesterone follows a pattern similar to changes in concentrations of a uterine chymotrypsin-like enzyme. Although the zona lysin may be a uterine-specific product, plasma transudates of zymogens or enzymes may also be involved since oestrogen-induced uptake of plasminogen by the mouse uterus has been reported (Finlay et al., 1983). Embryos are capable of producing plasminogen activator (Strickland, Reich \& Sherman, 1976; Sherman, Strickland \& Reich, 1976; Fazleabas, Geisert, Bazer \& Roberts, 1983) and the presence of uterine plasminogen serves as a convenient source of protease which the embryo is capable of activating to plasmin and possibly utilizing for either hatching or implantation. In an effort to examine the effects of plasmin and its zymogen, plasminogen, a simple embryo culture medium was supplemented with these proteins and subsequent embryonic development was compared with that in unsupplemented medium, media with trypsin or pronase, and medium with serum.

\section{Materials and Methods}

Pubertal Swiss-Webster female mice were maintained in a light cycle of $14 \mathrm{~h}$ light (06:00-20:00 h) and $10 \mathrm{~h}$ dark at $22^{\circ} \mathrm{C}$ and were fed and watered ad libitum. The oestrous cycles were synchronized and superovulation was induced with 10 i.u. PMSG (Calbiochem-Behring, San Diego, CA, U.S.A.) followed $4448 \mathrm{~h}$ later with 10 i.u. hCG (Calbiochem-Behring). Treated females were placed with a proven breeder male, one per cage, in the late afternoon on the day of the hCG injection. Females were observed for the presence of a vaginal plug the following morning, as evidence of mating. Mated females were killed by cervical dislocation between 07:00 and 10:00 h, about $24 \mathrm{~h}$ after detection of the vaginal plug, and the excised oviducts were flushed in retrograde fashion with Whitten's medium (Whitten \& Biggers, 1968) lacking bovine serum albumin (BSA). Two-cell embryos were collected, washed in several microdrops of Whitten's medium with $10 \mathrm{mg} \mathrm{BSA} / \mathrm{ml}$ (WM; Sigma Chemical Co., St Louis, MO, U.S.A.) under paraffin oil (Saybolt viscosity 125/135, Fisher Scientific, Santa Clara, CA, U.S.A.), morphologically evaluated and randomly distributed amongst 17 treatments. Two-cell embryos (50) were assigned to each of the following treatments: WM as the control medium, WM with $2 \cdot 3,4 \cdot 6,23 \cdot 1$ or $46 \cdot 2 \mu \mathrm{g}$ plasmin/ml, WM with $14 \cdot 6,29 \cdot 1$ or $145.7 \mu \mathrm{g}$ plasminogen $/ \mathrm{ml}$, WM with 0.1 or $0.2 \mu \mathrm{g}$ trypsin $/ \mathrm{ml}$, WM with 0.2 or $0.3 \mu \mathrm{g}$ pronase $/ \mathrm{ml}$ and Whitten's medium supplemented with $10 \%$ heat-treated bovine serum. Two-cell embryos (49) were also assigned to treatments of WM $+1 \cdot 1$ or $2.2 \mu \mathrm{g}$ trypsin/ml and $\mathrm{WM}+1.6$ or $3.3 \mu \mathrm{g}$ pronase/ml. Plasmin (EC 3.4.21.7), plasminogen and trypsin (EC 3.4.21.4) were obtained from Sigma Chemical Co. Pronase was obtained from Calbiochem-Behring. Serum used for supplementation was pooled from three cyclic cows and heat-treated at $56^{\circ} \mathrm{C}$ for $30 \mathrm{~min}$. All enzymes and zymogens were prepared as stock solutions and the protein concentrations were verified using the BioRad protein assay (BioRad Laboratories, Richmond, CA, U.S.A.) with BSA as the standard. In each microdrop 7-12 embryos were cultured under paraffin oil in uncoated, plastic $15 \times 60 \mathrm{~mm}$ tissue culture dishes in an humidified atmosphere of $5 \% \mathrm{CO}_{2}$ in air at $37^{\circ} \mathrm{C}$ and observations were conducted daily. After 10 days of culture, the media were collected and frozen to $-20^{\circ} \mathrm{C}$ until assayed for proteolytic activity.

Proteolytic activities in each of the treatments were determined at the initiation and termination of the culture period using a caseinolytic agar gel assay (BioRad Laboratories, Richmond, CA, U.S.A.). Aliquants of the culture $(25 \mu \mathrm{l})$ media were placed into wells cut in the bovine casein-agar gel plate and incubated at room temperature for $30 \mathrm{~h}$. Plates were then fixed for 10 min with $3 \%$ 
acetic acid, rinsed in tap water and the diameters of the resulting lytic zones measured using a vernier caliper. To evaluate any embryonic contribution of protease to the culture media as well as enzymic contaminants, microdrops of media without embryos were incubated under identical conditions for the same duration.

Ring diameters of the lytic zones on the casein-agar gel plates at the start and end of the cultures were analysed using the pooled $t$ test. Differences in the numbers of embryos developing into blastocysts, hatched blastocysts, attached blastocysts and attached blastocysts with trophoblastic outgrowth due to the culture conditions were evaluated using $\chi^{2}$ procedures.

\section{Results}

Proteolytic activities, expressed as ring diameters of the caseinolytic zones, of the various culture media used in the experiment are reported in Table 1. Media WM and WM + HTBS failed to exhibit any protease activity at the start or end of the culture period, and hence are excluded from the tables. Serum-supplemented media will exhibit protease activity if preincubated with a plasminogen activator like urokinase, but protease inhibitors present in serum also obscure detection of proteolytic activity. At the start of culture, proteolytic activity was detected in all plasminogensupplemented media and was estimated electrophoretically and by the caseinolytic agar gel assay as possessing about $20 \%$ contamination with plasmin. Incubation for 10 days with subsequent freezing reduced activities in media supplemented with plasmin, plasminogen and pronase but seemed to

Table 1. Proteolytic activities in Whitten's medium (WM) supplemented with plasmin, plasminogen, trypsin or pronase at the start and end of culture

\begin{tabular}{|c|c|c|c|c|c|c|}
\hline \multirow[b]{4}{*}{ Treatment } & \multicolumn{6}{|c|}{ Ring diameter $(\mathrm{cm})^{*}$} \\
\hline & & & & Enc & ture & \\
\hline & \multicolumn{2}{|c|}{ Start of culture } & \multicolumn{2}{|c|}{ Without embryos } & \multicolumn{2}{|c|}{ With embryos } \\
\hline & $n$ & Mean \pm s.d. & $n$ & Mean \pm s.d. & $n$ & Mean \pm s.d. \\
\hline \multicolumn{7}{|l|}{ WM + plasmin } \\
\hline $2.3 \mu \mathrm{g} / \mathrm{ml}$ & 2 & $0.80 \pm 0.04$ & 3 & $-\dagger$ & 4 & $-\dagger$ \\
\hline $4.6 \mu \mathrm{g} / \mathrm{ml}$ & 3 & $0.95 \pm 0.01$ & 3 & $-\dagger$ & 4 & 一† \\
\hline $23 \cdot 1 \mu \mathrm{g} / \mathrm{ml}$ & 3 & $1.21 \pm 0.02$ & 3 & $0.65 \pm 0.08^{\mathrm{a}}$ & 4 & $0 \cdot 66 \pm 0 \cdot 11^{\mathrm{a}}$ \\
\hline $46.2 \mu \mathrm{g} / \mathrm{ml}$ & 3 & $1.61 \pm 0.02$ & 3 & $0.95 \pm 0.06^{\mathrm{a}}$ & 5 & $0.97 \pm 0.04^{\mathrm{a}}$ \\
\hline \multicolumn{7}{|c|}{$\mathrm{WM}+$ plasminogen } \\
\hline $14.6 \mu \mathrm{g} / \mathrm{ml}$ & 3 & $0.69 \pm 0.03$ & 3 & $0.51+0.01^{\mathrm{a}}$ & 3 & $0.99+0.12^{\mathrm{b}}$ \\
\hline $29.1 \mu \mathrm{g} / \mathrm{ml}$ & 3 & $0.78 \pm 0.02$ & 3 & $0.72 \pm 0.05^{\mathrm{a}}$ & 5 & $1 \cdot 15 \pm 0.09^{b}$ \\
\hline $145.7 \mu \mathrm{g} / \mathrm{ml}$ & 3 & $1.30 \pm 0.01$ & 3 & $1.08 \pm 0.06^{\mathrm{a}}$ & 4 & $1 \cdot 30 \pm 0.04^{\mathrm{b}}$ \\
\hline \multicolumn{7}{|l|}{ WM + trypsin } \\
\hline $0.1 \mu \mathrm{g} / \mathrm{ml}$ & 3 & $1.06 \pm 0.04$ & 4 & $1.06 \pm 0.05^{\mathrm{a}}$ & 3 & $1 \cdot 00+0 \cdot 10^{\mathrm{a}}$ \\
\hline $0.2 \mu \mathrm{g} / \mathrm{ml}$ & 3 & $1.30 \pm 0.02$ & 5 & $1.33 \pm 0.05^{\mathrm{a}}$ & 3 & $1 \cdot 28 \pm 0.08^{\mathrm{a}}$ \\
\hline $1 \cdot 1 \mu \mathrm{g} / \mathrm{ml}$ & 3 & $2 \cdot 16 \pm 0.03$ & 3 & $2 \cdot 25 \pm 0 \cdot 09^{\mathrm{a}}$ & 5 & $2 \cdot 29 \pm 0 \cdot 10^{\mathrm{a}}$ \\
\hline $2 \cdot 2 \mu \mathrm{g} / \mathrm{ml}$ & 3 & $2.48 \pm 0.06$ & 3 & $2 \cdot 31 \pm 0.03^{\mathrm{a}}$ & 5 & $2 \cdot 40 \pm 0 \cdot 11^{\mathrm{a}}$ \\
\hline \multicolumn{7}{|l|}{$\mathrm{WM}+$ pronase } \\
\hline $0.2 \mu \mathrm{g} / \mathrm{ml}$ & 3 & $1 \cdot 17 \pm 0.03$ & 6 & $-\dagger$ & 4 & $-\dagger$ \\
\hline $0.3 \mu \mathrm{g} / \mathrm{ml}$ & 3 & $1.40 \pm 0.03$ & 4 & $0.83 \pm 0.03^{\mathrm{a}}$ & 3 & $0.82 \pm 0.08^{\mathrm{a}}$ \\
\hline $1.6 \mu \mathrm{g} / \mathrm{ml}$ & 3 & $2.00 \pm 0.02$ & 3 & $1.51 \pm 0.02^{\mathrm{a}}$ & 4 & $1 \cdot 40+0.08^{\mathrm{a}}$ \\
\hline $3.3 \mu \mathrm{g} / \mathrm{ml}$ & 3 & $2 \cdot 16 \pm 0 \cdot 05$ & 3 & $1.65 \pm 0.08^{\mathrm{a}}$ & 5 & $1.61 \pm 0.11^{\mathrm{a}}$ \\
\hline
\end{tabular}

* Diameter of lytic zone on the bovine casein-agar gel plate.

† Not detectable.

Means in the same row without common superscripts are different $(P<0.01)$. 
have little effect on trypsin activity. At the end of the culture period no significant differences in ring diameters were observed for plasmin-, trypsin- and pronase-supplemented media due to the presence of the embryos. However, plasminogen-supplemented media containing embryos exhibited significant increases in ring diameters when compared to media lacking embryos for all three concentrations used.

The incidences of blastocyst formation, hatching, attachment to the substratum and generation of trophoblastic outgrowth for embryos cultured in the various media are presented in Table 2. Embryonic development to the blastocyst stage was lower in all media supplemented with pronase and in Medium WM +1.1 or $2.2 \mu \mathrm{g}$ trypsin $/ \mathrm{ml}$ than in the control medium, WM $(P<0.05)$. A significant difference in the percentage of embryos developing into blastocysts was not observed between Medium WM and Medium WM 0.1 or $0.2 \mu \mathrm{g}$ trypsin $/ \mathrm{ml}$ although fewer blastocysts were formed in Medium WM $+0 \cdot 2 \mu \mathrm{g}$ trypsin $/ \mathrm{ml}$. Blastocyst formation in plasmin-, plasminogen- and serum-supplemented media appeared to be slightly improved over that observed in Medium WM, although significant increases were only observed in Medium WM +2.3 or $23 \cdot 1 \mu \mathrm{g}$ plasmin $/ \mathrm{ml}$ and Medium WM $+14.6 \mu \mathrm{g}$ plasminogen $/ \mathrm{ml}$. Significant differences in blastocyst formation were not detected among media with plasmin, plasminogen or serum.

The incidence of hatched blastocysts which completely escaped from the zona pellucida was lower in Medium WM $+0.2 \mu \mathrm{g}$ pronase $/ \mathrm{ml}$ than in Medium WM $(P<0.05)$. No significant difference was observed in hatching among embryos cultured in Medium WM +0.1 or $0.2 \mu \mathrm{g}$ trypsin $/ \mathrm{ml}$, Medium WM $+0 \cdot 3 \mu \mathrm{g}$ pronase $/ \mathrm{ml}$ and Medium WM. Hatching could not be evaluated in media supplemented with the two higher levels of pronase and trypsin since by $72 \mathrm{~h}$ and $96 \mathrm{~h}$ of

Table 2. Development of mouse embryos in Whitten's medium (WM) supplemented with plasmin, plasminogen, trypsin, pronase and heat-treated bovine serum ( + HTBS)

\begin{tabular}{|c|c|c|c|c|c|}
\hline \multirow[b]{2}{*}{ Treatment } & \multirow[b]{2}{*}{$n$} & \multicolumn{4}{|c|}{ Number of embryos $(\%)^{*}$} \\
\hline & & Blastocysts & $\begin{array}{l}\text { Hatched } \\
\text { blastocysts }\end{array}$ & $\begin{array}{c}\text { Attached } \\
\text { blastocysts }\end{array}$ & $\begin{array}{c}\text { Attached } \\
\text { blastocysts } \\
\text { with outgrowth }\end{array}$ \\
\hline WM & 50 & $42(84)^{c, d}$ & $21(42)^{b, c}$ & $21(42)^{\mathrm{c}, \mathrm{d}}$ & $2(4)^{\mathrm{a}, \mathrm{b}}$ \\
\hline $\begin{array}{r}\mathrm{WM}+\text { plasmin } \\
2.3 \mu \mathrm{g} / \mathrm{ml} \\
4.6 \mu \mathrm{g} / \mathrm{ml} \\
23 \cdot 1 \mu \mathrm{g} / \mathrm{ml} \\
46.2 \mu \mathrm{g} / \mathrm{ml}\end{array}$ & $\begin{array}{l}50 \\
50 \\
50 \\
50\end{array}$ & $\begin{array}{l}49(98)^{e} \\
48(96)^{d, e} \\
49(98)^{\mathrm{e}} \\
48(96)^{d, e}\end{array}$ & $\begin{array}{l}41(82)^{\mathrm{e}} \\
37(74)^{\mathrm{d}, \mathrm{e}} \\
41(82)^{\mathrm{e}} \\
37(74)^{\mathrm{d}, \mathrm{e}}\end{array}$ & $\begin{array}{l}41(82)^{f} \\
37(74)^{e, f} \\
39(78)^{e, f} \\
37(74)^{e, f}\end{array}$ & $\begin{array}{l}25(50)^{\text {e.f }} \\
24(48)^{d, e, f} \\
20(40)^{d, e, f} \\
14(28)^{\text {c,d }}\end{array}$ \\
\hline $\begin{array}{c}\mathrm{WM}+\text { plasmin } \\
14.6 \mu \mathrm{g} / \mathrm{ml} \\
29.1 \mu \mathrm{g} / \mathrm{ml} \\
145.7 \mu \mathrm{g} / \mathrm{ml}\end{array}$ & $\begin{array}{l}50 \\
50 \\
50\end{array}$ & $\begin{array}{l}49(98)^{\mathrm{e}} \\
44(88)^{\mathrm{d}, \mathrm{e}} \\
44(88)^{\mathrm{d}, \mathrm{e}}\end{array}$ & $\begin{array}{l}39(78)^{\mathrm{d}, \mathrm{e}} \\
31(62)^{\mathrm{c}, \mathrm{d}} \\
37(74)^{\mathrm{d}, \mathrm{e}}\end{array}$ & $\begin{array}{l}39(78)^{\mathrm{e}, \mathrm{f}} \\
31(62)^{\mathrm{d}, \mathrm{e}} \\
37(74)^{\mathrm{e}, \mathrm{f}}\end{array}$ & $\begin{array}{l}29(58)^{\mathrm{f}} \\
17(34)^{\mathrm{c}, \mathrm{d}, \mathrm{e}} \\
21(42)^{\mathrm{d}, \mathrm{e}, \mathrm{f}}\end{array}$ \\
\hline $\begin{array}{r}\mathrm{WM}+\text { trypsin } \\
0 \cdot 1 \mu \mathrm{g} / \mathrm{ml} \\
0 \cdot 2 \mu \mathrm{g} / \mathrm{ml} \\
1 \cdot 1 \mu \mathrm{g} / \mathrm{ml} \\
2 \cdot 2 \mu \mathrm{g} / \mathrm{ml}\end{array}$ & $\begin{array}{l}50 \\
50 \\
49 \\
49\end{array}$ & $\begin{array}{c}42(84)^{\mathrm{c}, \mathrm{d}} \\
34(68)^{\mathrm{b}, \mathrm{c}} \\
25(51)^{\mathrm{b}} \\
7(14)^{\mathrm{a}}\end{array}$ & $\begin{array}{c}21(42)^{\mathrm{b}, c} \\
18(36)^{\mathrm{b}} \\
\ldots+ \\
\ldots+\end{array}$ & $\begin{array}{l}16(32)^{\mathrm{c}} \\
16(32)^{\mathrm{c}} \\
18(37)^{\mathrm{c}} \\
5(10)^{\mathrm{a}, \mathrm{b}}\end{array}$ & $\begin{array}{l}0(0)^{\mathrm{a}} \\
1(2)^{\mathrm{a}} \\
4(8)^{\mathrm{a}, \mathrm{b}} \\
1(2)^{\mathrm{a}}\end{array}$ \\
\hline $\begin{array}{r}\mathrm{WM}+\text { pronase } \\
0.2 \mu \mathrm{g} / \mathrm{ml} \\
0.3 \mu \mathrm{g} / \mathrm{ml} \\
1.6 \mu \mathrm{g} / \mathrm{ml} \\
3.3 \mu \mathrm{g} / \mathrm{ml}\end{array}$ & $\begin{array}{l}50 \\
50 \\
49 \\
49\end{array}$ & $\begin{array}{l}28(56)^{\mathrm{b}} \\
28(56)^{\mathrm{b}} \\
29(59)^{\mathrm{b}} \\
12(24)^{\mathrm{a}}\end{array}$ & $\begin{array}{c}8(16)^{\mathrm{a}} \\
18(36)^{\mathrm{b}} \\
-\dagger \\
-\dagger\end{array}$ & $\begin{array}{c}6(12)^{\mathrm{b}} \\
11(22)^{\mathrm{b}, \mathrm{c}} \\
16(33)^{\mathrm{c}} \\
0(0)^{\mathrm{a}}\end{array}$ & $\begin{array}{l}0(0)^{\mathrm{a}} \\
1(2)^{\mathrm{a}} \\
8(16)^{\mathrm{b}, \mathrm{c}} \\
0(0)^{\mathrm{a}}\end{array}$ \\
\hline WM + HTBS & 50 & $45(90)^{\mathrm{d}, \mathrm{e}}$ & $30(60)^{\mathrm{c}, \mathrm{d}}$ & $30(60)^{\mathrm{d}, \mathrm{e}}$ & $30(60)^{\mathrm{r}}$ \\
\hline
\end{tabular}

* Values in parentheses are the percentages of two-cell embryos which developed to a particular cell stage.

$\dagger$ Not applicable since all zonae pellucidae had dissolved before the time of hatching.

Values in the same column without common superscripts are different $(P<0.05)$. 


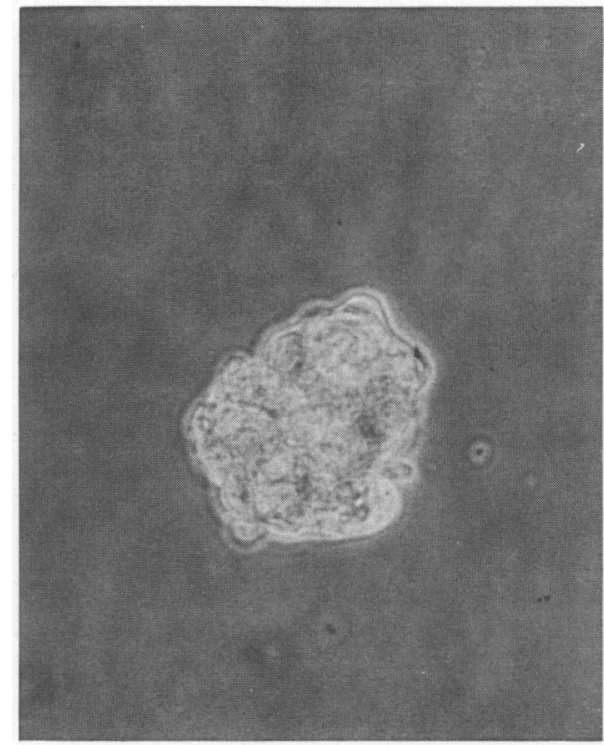

(a)

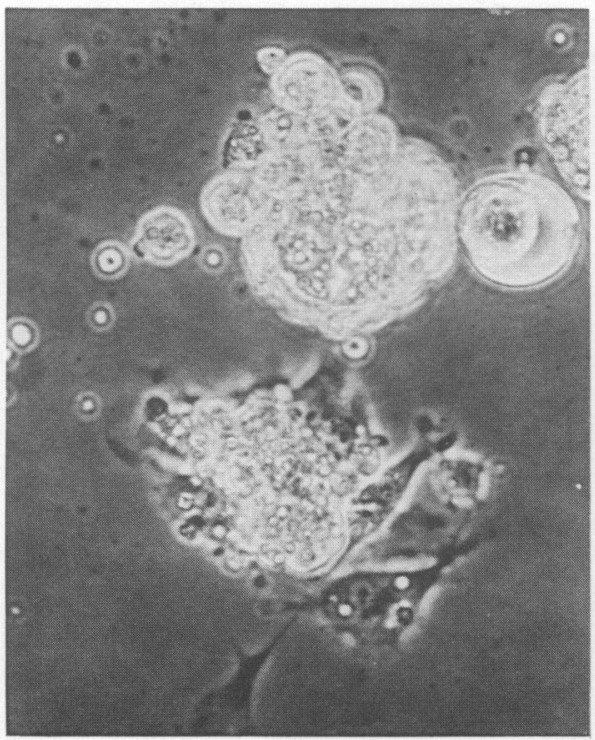

(c)

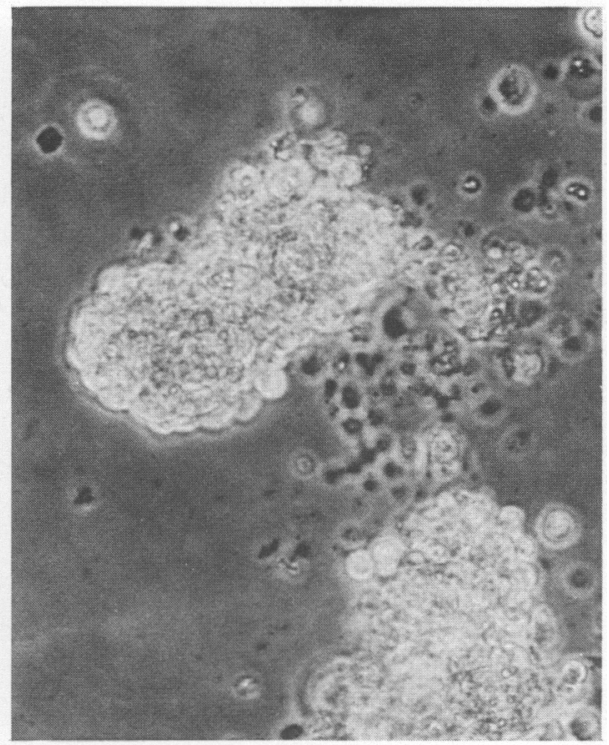

(b)

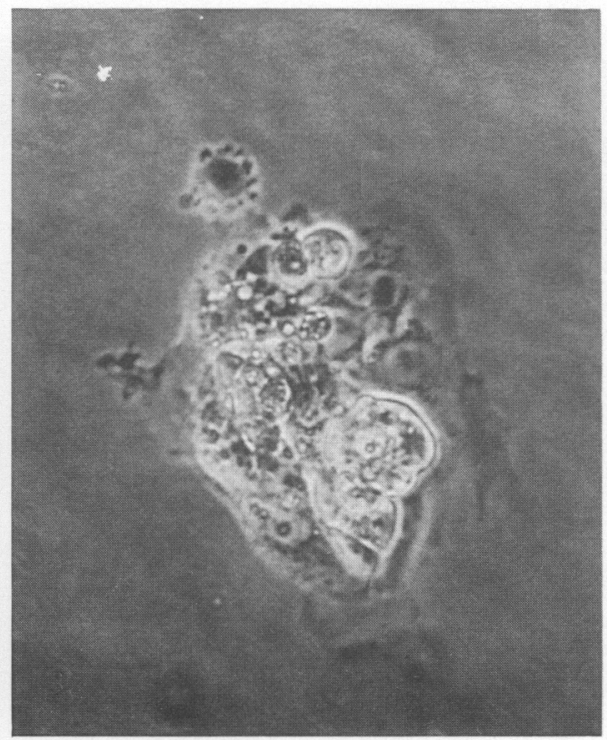

(d)

Fig. 1. Attached mouse blastocysts, $\times 360$. (a) Cultured for $168 \mathrm{~h}$ in Whitten's medium: (b) cultured for $120 \mathrm{~h}$ in Whitten's medium with $1 \cdot 1 \mu \mathrm{g}$ trypsin ml: (c) one blastocyst demonstrating trophoblastic outgrowth, after $120 \mathrm{~h}$ in Whitten's medium with $1.6 \mu \mathrm{g}$ pronase $\mathrm{ml}$ : (d) with trophoblastic outgrowth after $120 \mathrm{~h}$ in Whitten's medium with $10 \%$ heat-treated bovine serum. 


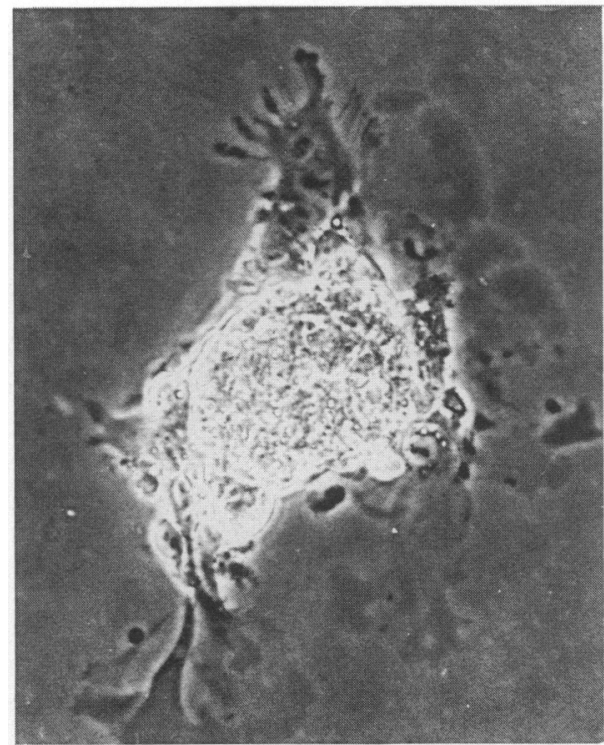

(a)

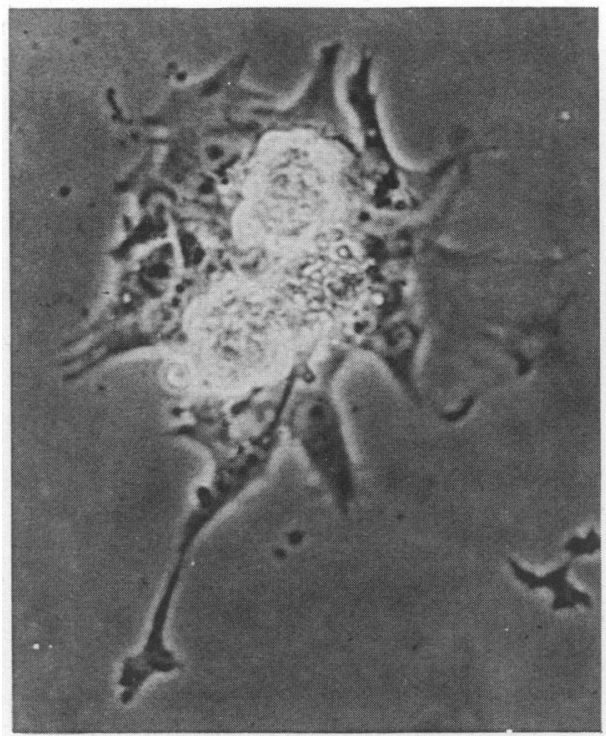

(c)

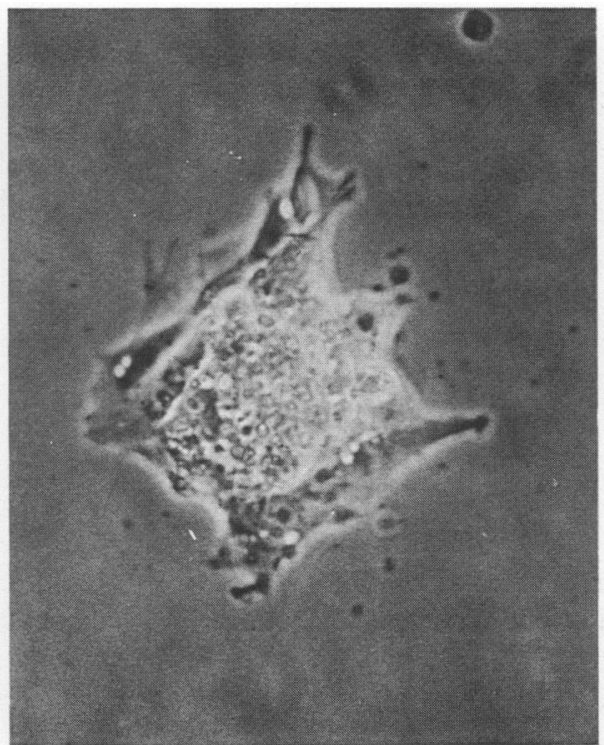

(b)

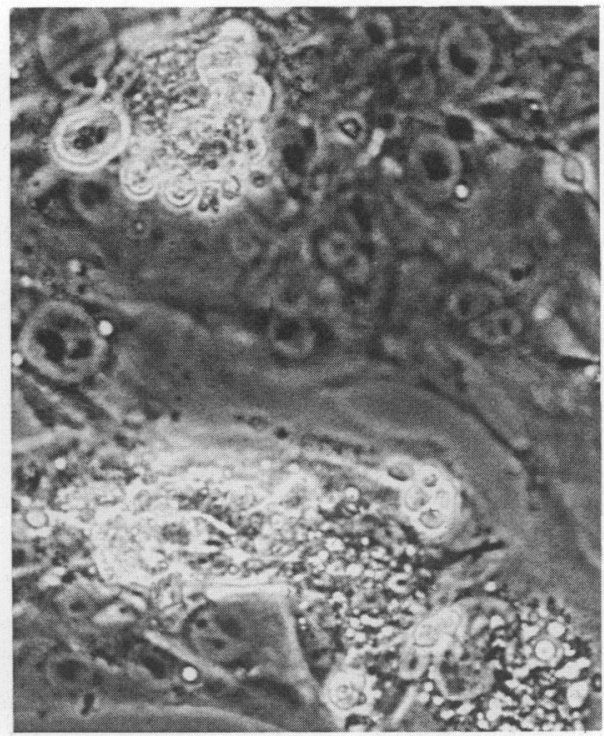

(d)

Fig. 2. Attached mouse blastocysts with trophoblastic outgrowths, $\times 360$. (a) Cultured for $120 \mathrm{~h}$ in Whitten's medium with $2.3 \mu \mathrm{g}$ plasmin ml: (b) after $144 \mathrm{~h}$ in Whitten's medium with $14.6 \mu \mathrm{g}$ plasminogen ml. (c) cultured for $144 \mathrm{~h}$ in a Whitten's medium with $23.1 \mu \mathrm{g}$ plasmin $/ \mathrm{ml}$ : (d) after $168 \mathrm{~h}$ in Whitten's medium with $10 \%$ heal-treated bovine serum. 
culture, respectively, all zonae pellucidae had dissolved. Shed zonae pellucidae remained intact in all other media. Greater numbers of embryos hatched in media supplemented with plasmin, plasminogen and serum than in Medium WM $(P<0.05)$, but a significant difference was not observed for Medium WM and Medium WM $+29 \cdot 1 \mu \mathrm{g}$ plasminogen $/ \mathrm{ml}$ and Medium WM + HTBS, despite differences of $20 \%$ and $18 \%$, respectively. The incidence of hatching was generally similar amongst embryos cultured in media with plasmin, plasminogen and serum $(P>0.05)$, although greater numbers of embryos hatched in Medium WM +2.3 or $23.1 \mu \mathrm{g}$ plasmin $/ \mathrm{ml}$ than in Medium $\mathrm{WM}+29 \cdot 1 \mu \mathrm{g}$ plasminogen $/ \mathrm{ml}$ and Medium WM + HTBS $(P<0.05)$.

Hatching was closely followed by attachment to the culture dish substratum of most of the embryos. Attachment was lower in Medium WM +0.2 or $3.3 \mu \mathrm{g}$ pronase $/ \mathrm{ml}$ and Medium $\mathrm{WM}+2.2 \mu \mathrm{g}$ trypsin $/ \mathrm{ml}$ than in Medium WM $(P<0.05)$. Significant differences in attachment rates were not observed amongst Medium WM, Medium WM $+0 \cdot 1,0.2$ or $1 \cdot 1 \mu \mathrm{g}$ trypsin $/ \mathrm{ml}$ and Medium WM +0.3 or $1.6 \mu \mathrm{g}$ pronase $/ \mathrm{ml}$, despite a $20 \%$ reduction in Medium $\mathrm{WM}+0.3 \mu \mathrm{g}$ pronase $/ \mathrm{ml}$ when compared to Medium WM (Figs la and b). Attachment was generally similar $(P>0.05)$ amongst plasmin- and plasminogen-supplemented media except for Medium $\mathrm{WM}+29 \cdot 1 \mu \mathrm{g}$ plasminogen $/ \mathrm{ml}$ which was significantly less than in Medium $\mathrm{WM}+2 \cdot 3 \mu \mathrm{g}$ plasmin $/ \mathrm{ml}$. Attachment rates were not different $(P>0.05)$ when Medium WM was compared to Medium WM $+29 \cdot 1 \mu \mathrm{g}$ plasminogen $/ \mathrm{ml}$ and Medium WM + HTBS despite differences of $20 \%$ and $18 \%$, respectively.

Attached blastocysts which exhibited adherent trophoblast cells that extended from the central mass of the embryo in a fashion similar to fibroblasts were scored as exhibiting trophoblastic outgrowth. The incidences of attached blastocysts which generated trophoblastic outgrowths were lowest in Medium WM and media supplemented with trypsin and pronase $(P<0.05)$. Significant differences in trophoblastic outgrowth were not observed between Medium WM and pronase- or trypsin-supplemented media, although a greater $(P<0.05)$ incidence was detected in Medium $\mathrm{WM}+1.6 \mu \mathrm{g}$ pronase $/ \mathrm{ml}$ when compared to other levels of pronase supplementation (Fig. 1c). Media supplemented with $46.2 \mu \mathrm{g}$ plasmin $/ \mathrm{ml}$ and $29.1 \mu \mathrm{g}$ plasminogen $/ \mathrm{ml}$ supported statistically similar, although greater, incidences of trophoblastic outgrowth than did Medium WM $+1.6 \mu \mathrm{g}$ pronase $/ \mathrm{ml}$. Similar numbers of embryos attached and formed trophoblastic outgrowths amongst Medium WM $+2 \cdot 3,4 \cdot 6$ or $23 \cdot 1 \mu \mathrm{g}$ plasmin $/ \mathrm{ml}$, Medium $\mathrm{WM}+14 \cdot 6$ or $145 \cdot 7 \mu \mathrm{g}$ plasminogen $/ \mathrm{ml}$ and Medium WM + HTBS (Figs 1d, 2a, 2b, 2c). Although not statistically significant, a trend existed whereby greater incidences of trophoblastic outgrowth were supported in media with lower levels of plasmin and plasminogen.

\section{Discussion}

In mouse embryos, plasminogen activator follows a temporally biphasic pattern of secretion (Strickland et al., 1976). Production of plasminogen activator during the first phase of secretion is by both trophoblast and inner cell mass and can be detected by Day 6 post coitum (Sherman et al., 1976). Trophoblastic production of plasminogen activator corresponds to the period when the trophoblast is invasive and is believed to be responsible for generating plasmin to facilitate implantation (Strickland et al., 1976; Sherman et al., 1976). Embryonic plasminogen activator production, measured indirectly by the formation of plasmin in plasminogen-containing media, was also observed in this study. Secretion of any other embryonic proteases was not detected using the caseinolytic agar gel assay since after 10 days of culture proteolytic activity was not observed in the control medium, WM, or seen to increase in media supplemented with enzymes other than plasminogen. Since only the medium was assayed in the present experiment, this does not exclude the secretion of low levels of proteases which are undetectable using the caseinolytic agar gel assay or the presence of membrane-bound proteases not released into the medium. Using histochemical techniques, Denker \& Hafez (1975) and Denker (1977) have identified a trypsin-like proteinase, 
referred to as blastolemmase, associated with dissolution of the rabbit blastocyst coverings. The source of this particular enzyme may be the trophoblast, although embryonic uptake of this protein as a zymogen produced by the uterus followed by trophoblastic activation to the active form is an alternative proposed by Denker (1977).

Proteases have been reported as inducing growth factor-like effects on various cell types in vitro (Cunningham, 1981). Mitogenic effects induced by proteases vary, however, and are dependent on the protease-cell type combination. Limited proteolysis at the cell surface has been postulated as resulting in the breakdown of an inhibitor of cell division or the activation of a mitotic stimulator, both of which can be membrane components (Cunningham, 1981). The significance of a generalized protease effect stimulating embryo development is not readily evident from the data presented. Pronase at $0 \cdot 2 \mu \mathrm{g} / \mathrm{ml}$ possessed a proteolytic activity comparable to plasmin at $23 \cdot 1 \mu \mathrm{g} / \mathrm{ml}$, yet the incidence of blastocyst formation was far lower in medium with pronase. A reasonable explanation may be that the pronase disrupted cell surface proteins integral to development which were not affected by plasmin. Fewer embryos hatched in Medium with $0 \cdot 2 \mu \mathrm{g}$ pronase $/ \mathrm{ml}$ than Medium with $0.3 \mu \mathrm{g}$ pronase $/ \mathrm{ml}$ despite identical incidences of blastocyst formation. One reason for this effect may be due to a structural weakening of the zona pellucida in the higher level of pronase that facilitated blastocyst escape. The higher incidence of attachment with subsequent trophoblastic outgrowth by embryos cultured in Medium WM $+1.6 \mu \mathrm{g}$ pronase/ $\mathrm{ml}$ over the lower levels is no doubt due to these embryos not requiring hatching since dissolution of the zona pellucida had previously occurred. Except for the two higher levels, trypsin did not appear to have much of an effect on embryo development. The addition of trypsin at 0.1 or $0 \cdot 2 \mu \mathrm{g} / \mathrm{ml}$ to the culture media, although providing a significant quantity of protease, had no significant effect on embryo development when compared to performance by embryos in control medium. Trypsin at the two lower concentrations did not affect zona pellucida dissolution as observed in the two higher levels, and apparently had no influence on zona pellucida integrity since the rate of hatching was not different from that of the control.

Development in plasmin- and plasminogen-supplemented media was similar to that observed in medium with serum. In fact, in some instances, e.g. hatching, significantly greater numbers of embryos completely escaped from the zona pellucida in plasmin-supplemented media than medium with serum. Plasmin contamination in the plasminogen containing media confounds interpretation of the results with regards to differentiating between the effects of plasmin and plasminogen on in-vitro embryo development. It is indeed possible that the similarities observed between media with plasmin and plasminogen, at least before embryonic activation of plasminogen has occurred, are due to the $20 \%$ plasmin contamination in the media with plasminogen. The observation that plasmin- and plasminogen-supplemented media supported greater incidences of blastocyst formation, hatching and trophoblastic outgrowth at proteolytic activities equivalent to pronase and trypsin suggests a very attractive physiological role for plasmin in early embryo development. Although detectable levels of plasminogen activator occur by Day 6 , this does not preclude earlier production of this enzyme. Plasminogen is a constituent of the uterine environment, and serves as a readily utilizable source of protease for the early embryo (Fazleabas et al., 1983). Plasminogen activation to plasmin may be a mechanism which the embryo uses to effect a 'sublysis' (Domon, Pinsker \& Mintz, 1973) of the zona pellucida to facilitate hatching. Menino \& Wright (1982) have observed a decrease in the resistance of the pig zona pellucida to pronase with advancing cell stage. Hoversland \& Weitlauf (1982) have also described enhanced solubility of the mouse zona pellucida in ovariectomized females treated with oestrogen and progesterone. Oestradiol stimulates uptake of several serum proteins, including plasminogen (Finlay et al., 1983), and so these sublytic effects on the zona pellucida may be due to embryonic conversion of plasminogen to plasmin. Plasmin may also have a growth stimulatory effect on embryos, which could account for the improved development. Kane (1983a, b) has shown that hatching by rabbit blastocysts in vitro was not dependent on proteolysis but was enhanced as embryo cell number increased. All embryos cultured in Medium WM + HTBS and becoming attached generated trophoblastic outgrowths. This did 
not occur in plasmin- or plasminogen-supplemented media in which only some attached embryos formed trophoblastic outgrowths. Moreover, the extent of the outgrowth, although not quantitatively scored, was greater in medium with serum (Fig. 2d). Overall, however, there were few differences in development of embryos in serum-, plasmin- and plasminogen-supplemented media. These results indicate that plasmin can induce and support trophoblastic outgrowth formation but some additional serum factors, possibly fibronectin (Ham, 1981), must also be involved since the extent of the outgrowth is reduced in serum-free media. Strickland et al. (1976) have observed attachment and trophoblastic outgrowth by embryos cultured in medium supplemented with plasminogen-depleted serum, and, under those conditions, therefore, plasmin apparently is not an integral effector of outgrowth.

This research was supported in part by NIH-MBRS Grant No. 2 SO6RR 08073-10A1.

\section{References}

Baskar, J.F., Torchiana, D.F., Biggers, J.D., Corey, E.J., Andersen, N.H. \& Subramanian, N. (1981) Inhibition of hatching of mouse blastocysts in vitro by various prostaglandin antagonists. $J$, Reprod. Fert. 63, 359-363.

Biggers, J.D., Leonov, B.V., Baskar, J.F. \& Fried, J. (1978) Inhibition of hatching of mouse blastocysts in vitro by prostaglandin antagonists. Biol. Reprod. 19, 519-533.

Cunningham, D.D. (1981) Proteases as growth factors. In Tissue Growth Factors, pp. 229-248. Ed. R. Baserga Springer-Verlag, New York.

Denker, H.W. (1977) Implantation: the role of proteinases and blockage of implantation by proteinase inhibitors. Adv. Anat. Embryol. Cell Biol. 53, 1-123.

Denker, H.W. \& Hafez, E.S.E. (1975) Proteases and implantation in the rabbit: role of trophoblast vs. uterine secretion. Cytobiologie 11, 101-109.

Domon, M., Pinsker, M.C. \& Mintz, B. (1973) Thiocyanate assay for sublytic change in the zona pellucida of the mouse egg. Biol. Reprod. 9, 246-253.

Fazleabas, A.T., Geisert, R.D., Bazer, F.W. \& Roberts, R.M. (1983) Relationship between release of plasminogen activator and estrogen by blastocysts and secretion of plasmin inhibitor by uterine endometrium in the pregnant pig. Biol. Reprod. 29 , 225-238.

Finlay, T.H., Katz, J., Kirsch, L., Levitz, M., Nathoo, S.A. \& Seiler, S. (1983) Estrogen-stimulated uptake of plasminogen by the mouse uterus. Endocrinology 112, 856-861.

Ham, R.G. (1981) Survival and growth requirements of nontransformed cells. In Tissue Growth Factors, pp. 13-88. Ed. R. Baserga. Springer-Verlag, New York.

Hoversland, R.C. \& Weitlauf, H.M. (1981) Lysis of the zona pellucida and attachment of embryos to the uterine epithelium in ovariectomized mice treated with oestradiol-17\% and progesterone. J. Reprod. Fert. 62, 111-116.

Hoversland, R.C. \& Weitlauf, H.M. (1982) In-vitro zona-lytic activity in uterine fluid from ovariectomized mice treated with oestradiol-17\% and progesterone. J. Reprod. Fert. 64, 223-226.
Hurst, P.R. \& MacFarlane, D.W. (1981) Further effects of nonsteroidal anti-inflammatory compounds on blastocyst hatching in vitro and implantation rates in the mouse. Biol. Reprod. 25, 777-784.

Joshi, M.S. \& Murray, I.M. (1974) Immunological studies of the rat uterine fluid peptidase. J. Reprod. Fert. 37, 361-365.

Kane, M.T. (1983a) Evidence that protease action is not specifically involved in the hatching of rabbit blastocysts caused by commercial bovine serum albumin in culture. J. Reprod. Fert. 68, 471-475.

Kane, M.T. (1983b) Variability in different lots of commercial bovine serum albumin affects cell multiplication and hatching of rabbit blastocysts in culture. J. Reprod. Fert. 69, 555-558.

McLaren, A. (1970) The fate of the zona pellucida in mice. J. Embryol. exp. Morph. 23, 1-19.

Menino, A.R., Jr \& Wright, R.W., Jr (1982) Variation in porcine zona pellucida morphology following pronase treatment. J. Anim. Sci. 55, 369-375.

Mintz, B. (1972) Implantation-initiating factor from mouse uterus. In Biology of Fertilization and Implantation, pp. 343-356. Eds K. S. Moghissi \& E. S. E. Hafez. Thomas, Springfield.

Rosenfeld, M.G. \& Joshi, M.S. (1977) A possible role of a specific uterine fluid peptidase in implantation in the rat. J. Reprod. Fert. 51, 137-139.

Rosenfeld, M.G. \& Joshi, M.S. (1981) Effect of a rat uterine fluid endopeptidase on lysis of the zona pellucida. J. Reprod. Fert. 62, 199-203.

Sherman, M.I., Strickland, S. \& Reich, E. (1976) Differentiation of early mouse embryonic and teratocarcinoma cells in vitro: plasminogen activator production. Cancer Res. 36, 4208 4216.

Strickland, S., Reich, E. \& Sherman, M.I. (1976) Plasminogen activator in early embryogenesis: enzyme production by trophoblast and parietal endoderm. Cell 9, 231-240.

Whitten, W.K. \& Biggers, J.D. (1968) Complete development in vitro of the pre-implantation stages of the mouse in a simple chemically defined medium. $J$. Reprod. Fert. 17, 399-401.

Received 20 August 1985 